\title{
Use of Biocatalysis and Future Prespectives
}

\author{
Greeshma Gopisetti* \\ Department of Biotechnology, Jawaharlal Nehru Technological University Hyderabad, Hyderabad, India
}

\begin{abstract}
The use of biocatalysts in the chemical reactions is well known from centuries and the present world is moving towards using this natural method of using biomolecules, especially enzymes or whole cells, a catalyst to fasten the process of reaction. Use of biocatalysis has expanded in last few decades, and it has impacted chemical synthesis in different industries including pharmaceuticals, fine chemicals, and food. This review discusses the current status in the field of bio catalytic engineering, biocatalysts and also the use of biocatalyst to overcome the hazards caused by the use of chemical and synthetic catalysts.
\end{abstract}

Keywords: Biocatalysis, Enzymes, Catalysts, Chemical reactions

\section{Introduction}

Biocatalysis is one of the oldest known chemical transformation methods to known since $18^{\text {th }}$ century. Biocatalysis is the use of enzymes, biomolecules as catalysts in chemical synthesis. These enzymes can be used in whole cell format or as isolated preparations, prepared either in their native cells or as recombinantly expressed proteins in alternate host cells [1]. The use of enzymes in pharmaceutical industry has increased dramatically in last few decades and it is safe to say we haven't scratched the surface of its applications.

Using biocatalysts has a capability to meet the increasing requirement of catalysts for the reactions, and its more safer than synthetically produced ones. Unlike the chemical catalysts, using biocatalysts can be modified easily due to its vast structures, multiple possibilities of docking [1] (Figure 1) with the substrate and its structure has made them more susceptible for easy changes and modifications based on the requirement of the reactions.

The pharmaceutical catalysts have become increasingly complex and the use of synthetic catalysts had a very bad impact on environment. In order to overcome the issue, more use of biocatalysts and natural catalysts has been evolved in the pharmaceutical industry [2].

Use of biocatalyst is low-cost, safer, and greener alternatives to traditional chemical and synthetic catalysts $[3,4]$.

\section{Environmental Friendly Biocatalysts}

Biocatalysts are often more economical than chemical catalysts. Economical and clean enzyme technologies would promote the sustainable processes for the production of food, feed and materials. The enzymes of most economical importance include amylases, glucose isomerase, proteases, cellulases, and lipases [5].

Enzymes can be considered as renewable catalysts [6]. Regular catalysts are normally metal based, that rely on mining and harsh, energy intensive processing and biocatalysts are biodegradable and easily replaced through inexpensive and environmental friendly [6].

Despite the clear benefits of biocatalytic processes, the historical number of applications has been modest, and any dramatic increase in the use of biocatalysis only occurred in the last two decades [1,2,7].

\section{Biocatalysts}

Natural reactions like photosynthesis for atmospheric $\mathrm{CO}_{2}$ fixation, $\mathrm{N}_{2}$ fixation are basic examples of biocatalytic reactions. These reactions are making our environment habitable for humans [8]. Another basic reaction that has dated back to ancient times is the release of enzymes in microorganisms.

*Correspondence to: Greeshma Gopisetti, Department of Biotechnology, Jawaharlal Nehru Technological University Hyderabad, India, E-mail: gn_greeshma@ yahoo.com

Citation: Gopisetti G (2020) Use of Biocatalysis and Future Prespectives. J Catal Chem Eng Adv 7(1): 101. DOI: https://doi.org/10.47275/2693-7182-101.

Received: June 08, 2020; Accepted: June 30, 2020; Published: July 05, 2020

Copyright: $\odot 2020$ Gopisetti G. This is an Open Access article distributed under the terms of the Creative Commons Attribution 4.0 International License (CCBY) (http://creativecommons.org/licenses/by/4.0/) which permits commercial use, including reproduction, adaptation, and distribution of the article provided the original author and source are credited. 


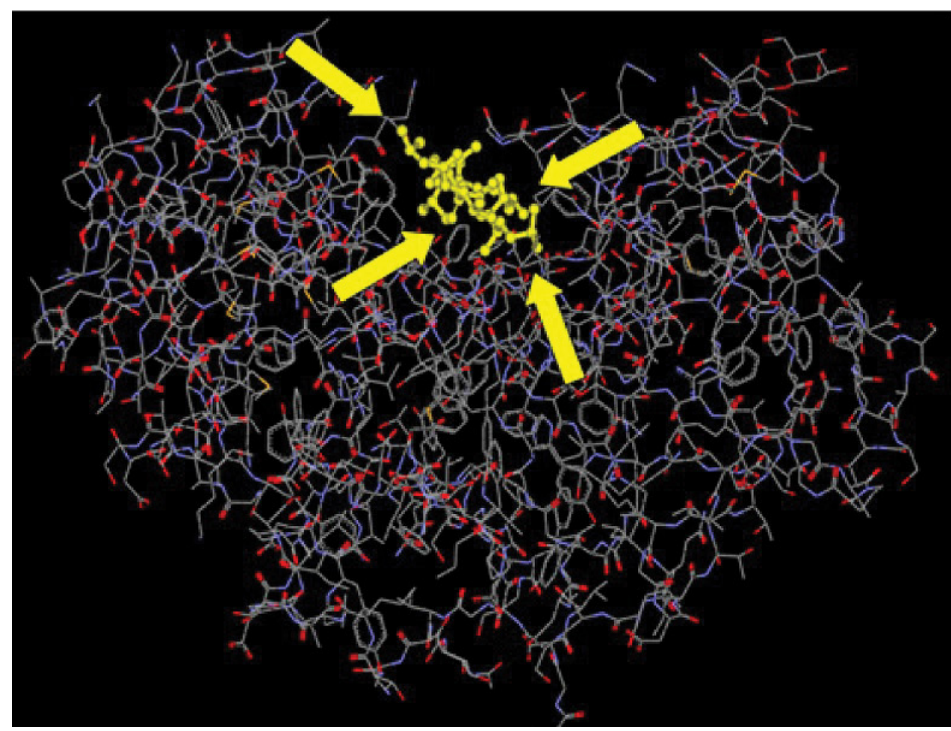

Figure 1: Representing the possibility of multiple docking sites for easy alterations [1].

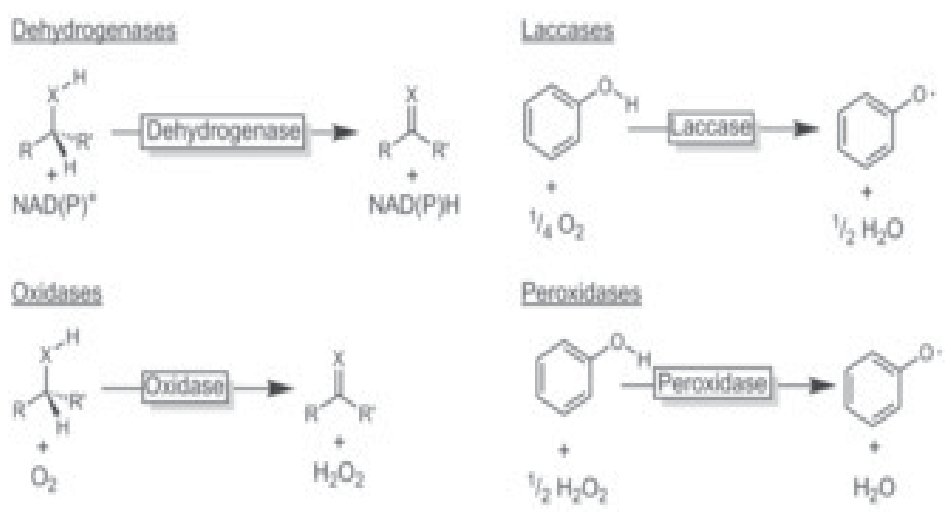

Figure 2: Biocatalytic oxidation reactions as provided in the article by Dong et al. [10].

The production of yeast in the beer production by fermentation process is one of the earliest method that can be linked to enzymes produced by microorganisms [9].

Advances made in the biocatalysis, and expansion of its application from natural fermentation processes to engineered biocatalytic systems involves isolated enzymes or whole cells with optimized functions, for the production of medicinal drugs, polymers or biofuels [9].

\section{Future of Biocatalysts}

The usage of biocatalysis has seen a continued growth in the pharmaceutical industry [1]. Advances in DNA sequencing and gene synthesis are at the base of tremendous progress in tailoring biocatalysts by protein engineering and design, and the ability to reorganize enzymes into new biosynthetic pathways [9].

Oxidoreductase catalysts for selective oxidation/reduction reactions are showing more good results. Biocatalytic oxidation reactions (Figure 2) can be categorized into dehydrogenation and oxyfunctionalisation reactions [10].

In present days, large amounts of waste such as green house gases and plastic gases being produced globally has become one of the vital threats to the environment and its sustainability. Biocatalysis could further improve of our lives and address these issues. Recycling of waste and emissions is only one part of the solution - reducing them is the other. Engineered and hybrid biocatalytic systems could play an important role in addressing these areas. "Recycling of waste and emissions is only one part of the solution - reducing them is the other. Engineered and hybrid biocatalytic systems could play an important role in addressing these areas" [11].

\section{References}

1. Truppo MD. 2017. Biocatalysis in the pharmaceutical industry: the need for speed. ACS Med Chem Lett 8(5): 476-480. https://doi.org/10.1021/acsmedchemlett.7b00114

2. Choi JM, Han SS, Kim HS. 2015. Industrial applications of enzyme biocatalysis: current status and future aspects. Biotechnol Adv 33(7): 1443-1454. https://doi.org/10.1016/j. biotechadv.2015.02.014 
3. Huisman GW, Collier SJ. 2013. On the development of new biocatalytic processes for practical pharmaceutical synthesis. Curr Opin Chem Biol 17(2): 284-292. https://doi.org/10.1016/j cbpa.2013.01.017

4. Tomsho JW, Pal A, Hall DG, Benkovic SJ. 2011. Ring structure and aromatic substituent effects on the pK a of the benzoxaborole pharmacophore. ACS Med Chem Lett 3(1): 48-52. https://doi.org/10.1021/ml200215j

5. McAuliffe JC, Aehle W, Whited GM, Ward DE. 2007. Industrial Enzymes and Biocatalysis. In: Kent JA (eds) Kent and Riegel's Handbook of Industrial Chemistry and Biotechnology. Springer, Boston, USA. https://doi.org/10.1007/978-0-387-27843-8_31

6. Hughes G, Lewis JC. 2018. Introduction: biocatalysis in industry. Chem Rev 118(1): 1-3. https://doi.org/10.1021/acs.chemrev.7b00741

7. Schmid A, Dordick JS, Hauer B, Kiener A, Wubbolts M, et al. 2001. Industrial biocatalysis today and tomorrow. Nature 409(6817): 258-268. https://doi.org/10.1038/35051736

8. Geider RJ, Delucia EH, Falkowski PG, Finzi AC, Grime JP, et al. 2002. Primary productivity of planet earth: biological determinants and physical constraints in terrestrial and aquatic habitats. Glob Chang Biol 7(8): 849-882. https://doi.org/10.1046/j.1365-2486.2001.00448.x

9. Bornscheuer UT, Huisman GW, Kazlauskas RJ, Lutz S, Moore JC, et al. 2012. Engineering the third wave of biocatalysis. Nature 485: 185-194. https://doi.org/10.1038/nature11117

10. Dong JJ, Fernández-Fueyo E, Hollmann F, Paul CE, Pesic M, et al. 2018. Biocatalytic oxidation reactions: a chemist’s perspective. Angew Chem Int Ed Engl 57(30): 9238-9261. https:// doi.org/10.1002/anie.201800343

11. Expanding biocatalysis for a sustainable future. Nat Catal 3: 179-180. https://doi.org/10.1038/s41929-020-0447-8 